\title{
Variations in Numbers of Median Dorsal Thorns and Rows of Teeth in Thorny Skate (Raja radiata) of the Northwest Atlantic
}

\author{
Wilfred Templeman \\ Department of Fisheries and Oceans, Fisheries Research Branch \\ Northwest Atlantic Fisheries Centre, P. O. Box 5667 \\ St. John's, Newfoundland, Canada A1C 5X1
}

\begin{abstract}
Data on the number of median dorsal thorns (anterior to the first dorsal fin) and the number of rows of teeth of the thorny skate from various areas of the Northwest Atlantic in 1949-72 were analyzed. The results showed a cline of mean number of median dorsal thorns from the Baffin Island and Ungava Bay areas southward along Labrador and eastern Newfoundland to the Grand Bank and thence westward to the Gulf of St. Lawrence, Scotian Shelf and Georges Bank, the higher numbers occurring at lower developmental temperatures and vice versa. The mean tooth-row counts showed a cline which was opposite to that for median dorsal thorns, increasing from the Baffin Island and Ungava Bay areas southward to the Scotian Shelf and Georges Bank. There was a slight tendency toward increased tooth-row numbers with fish length, but the within-area differences were not significant for lengths greater than $24 \mathrm{~cm}$ which were used in the comparisons among areas. Males tended to have slightly more rows of teeth than females, but there was no clear evidence of sexual dimorphism. The number of tooth-rows in the lower jaw was, on the average, slightly higher than in the upper jaw, but the upper-jaw counts exceeded the lower-jaw counts in small samples from the geographical extremes of the populations studied.
\end{abstract}

\section{Introduction}

The thorny skate (Raja radiata) is widely distributed in the northern part of the Northeast Atlantic (Andriyashev, 1954) and occurs from West Greenland and Baffin Island southward to South Carolina in the Northwest Atlantic (Bigelow and Schroeder, 1953; Templeman, 1982). It is the most common skate in the Newfoundland, Gulf of St. Lawrence, Scotian Shelf and Gulf of Maine areas (McEachran and Musick, 1975; Scott, 1982; Templeman, 1982, 1984). The reported catches of all skates in the Northwest Atlantic are not large at present, the nominal catch in 1981 being 4,500 (metric) tons (NAFO, 1983), of which 3,000 tons were taken off eastern and southern Newfoundland (NAFO Subarea 3) where the thorny skates are large. Large quantities of skates are caught and discarded, because most trawler fishermen retain only the desired groundfish species, such as Atlantic cod, haddock, Atlantic redfishes and various flounders.

The numbers of median dorsal thorns and tooth rows of thorny skates have been reported typically in studies of small numbers of museum specimens (Jensen, 1914, 1948; Clark, 1926; Bigelow and Schroeder, 1953), and these meristics have been used in distinguishing between species of skates. However, no large-scale study of between-area differences in these characters has been reported previously for the thorny skate. The variations in these meristic characters are of considerable scientific interest, and it was thought that they might also provide some evidence for discriminating between stocks of thorny skates in different areas. Research on meristic characters of other fishes often has provided important evidence on stock discrimination in, for example, Atlantic cod (Schmidt, 1930; Templeman, 1981) and haddock (Vladykov, 1935; Clark and Vladykov, 1960).

\section{Materials and Methods}

Research on the number of median dorsal thorns (anterior to the first dorsal fin) and the number of rows of teeth of thorny skates was carried out by the author during 1949-72. Collection of the data was incidental to research being conducted by research vessels on distribution and abundance of other species, and, consequently, the amounts of data from different areas of the Northwest Atlantic varied greatly, depending on the frequency of cruises to the areas. The distribution of thorny skate samples, from which the data for this paper were obtained, was the same as that reported by Templeman (1982), illustrated here as Fig. 1. The skates were measured as total length, to the nearest centimeter, from the tip of the snout to the end of the tail.

The large median dorsal thorns of the thorny skate are on radiate bases and can be recognized, particularly in the tail region, by flattening from side to side with a long point directed posteriorly (Fig. 2). The flattening is less noticeable anteriorly. The largest median thorn is usually in the mid-scapular region. 


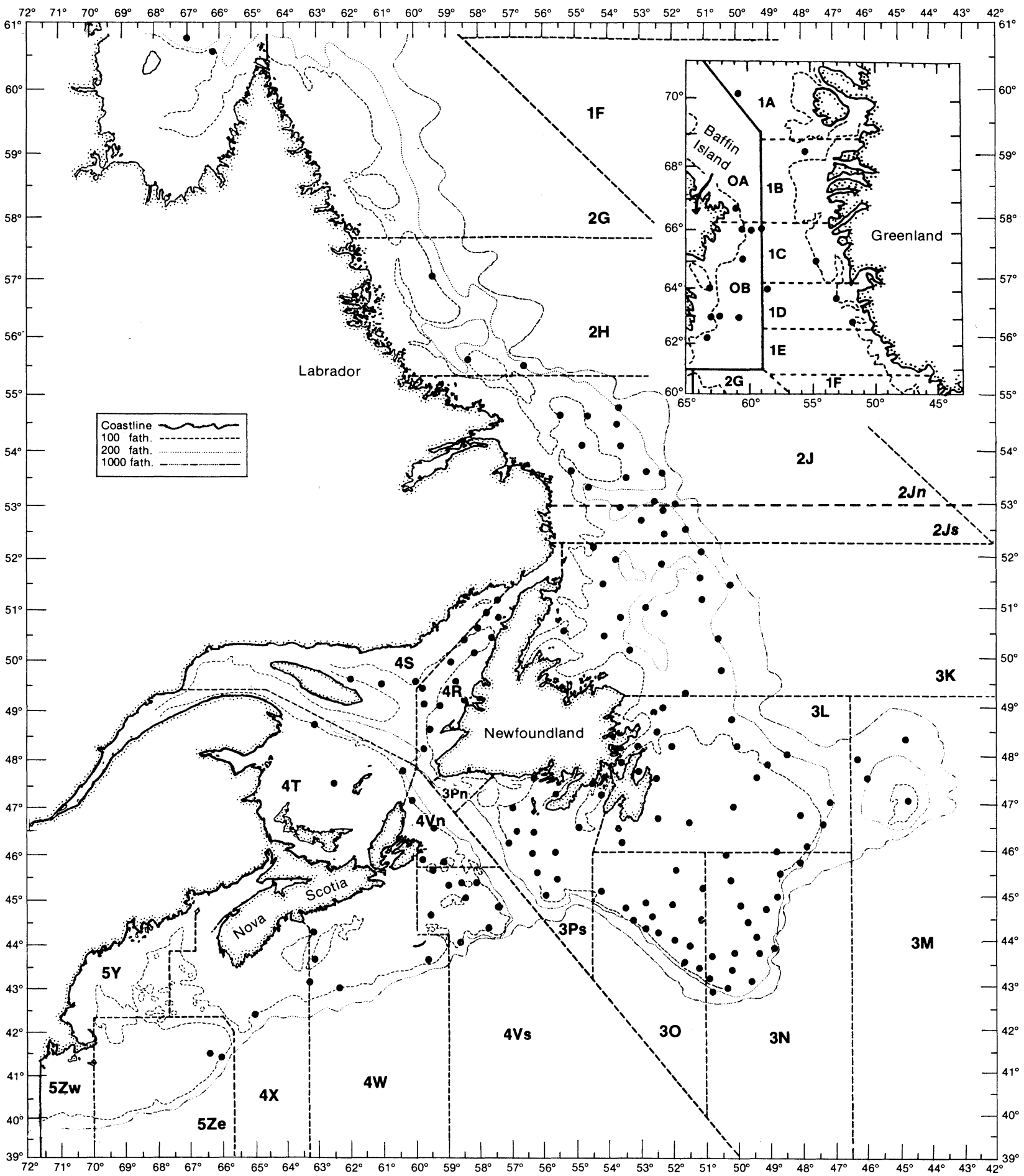

Fig. 1. Map of Northwest Atlantic showing locations of skate samples and the NAFO divisions mentioned in the text. (Thorny skates from the north coast of Iceland were taken in the area of $65^{\circ} 48^{\prime}-66^{\circ} 31^{\prime} \mathrm{N}$ and $17^{\circ} 28^{\prime}-20^{\circ} 39^{\prime} \mathrm{W}$ at $82-161 \mathrm{~m}$.)

There is one median thorn in front of the mid-scapular thorn, and this nuchal thorn was counted even when it was absent in occasional specimens. The counts of median dorsal thorns did not include the smaller, more rounded intermediate thorns which did not form part of the regular middorsal series. In large skates, where some median dorsal thorns were lost but visible scars remained, the counts included thorns and scars which clearly formed the regular series.

The teeth and tooth-rows of thorny skate were described and illustrated by Clark (1929) and Bigelow 


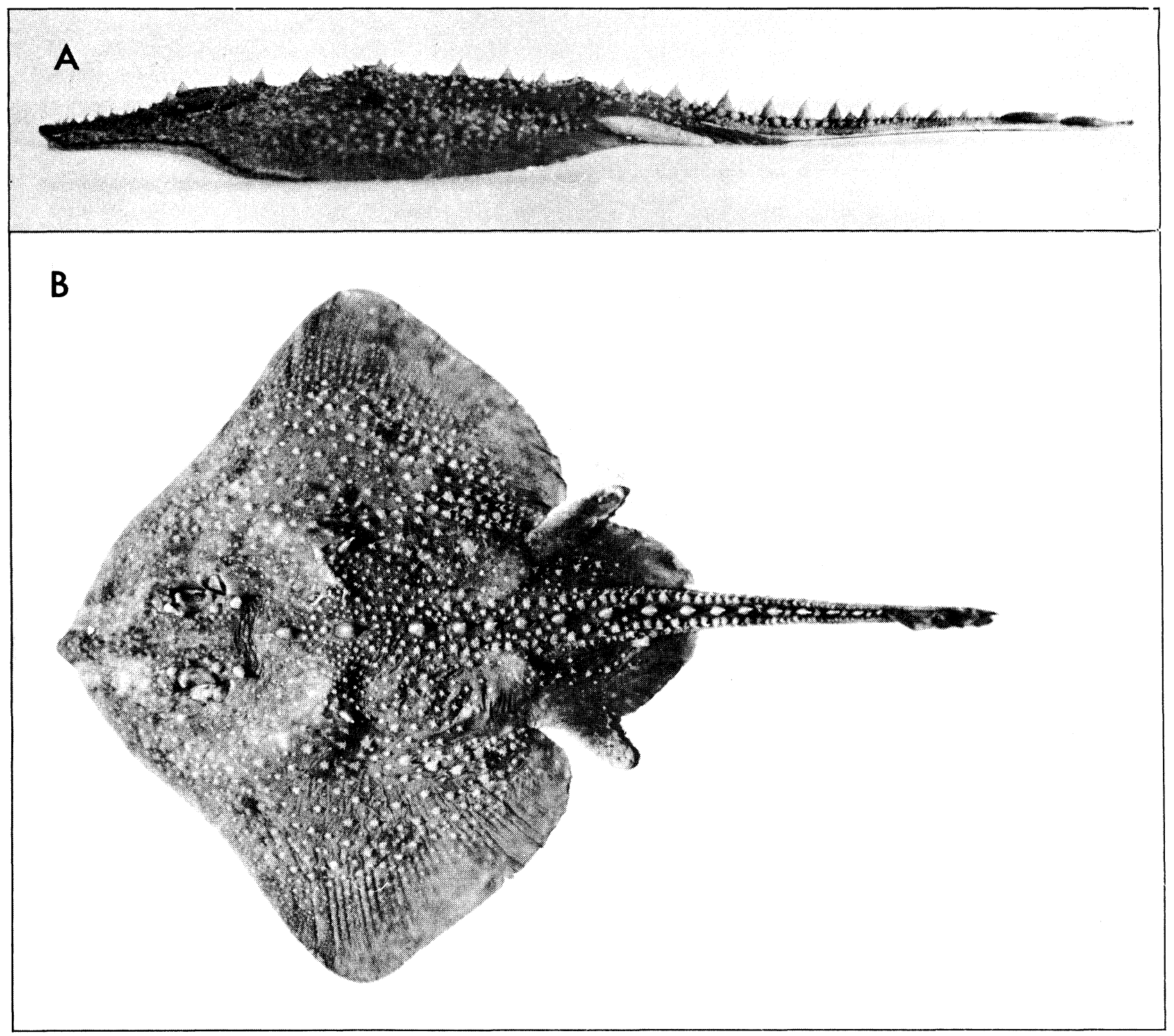

Fig. 2. Lateral (upper) and dorsal (lower) views of thorny skate to show the median dorsal thorns. (Immature female, $41 \mathrm{~cm}$ total length, 17 median dorsal thorns; from Hamilton Bank, $54^{\circ} 21^{\prime} \mathrm{N}-54^{\circ} 35^{\prime} \mathrm{W}$, September 1952.)

and Schroeder (1953) and illustrated by Jensen (1948). Tooth-row counts were made in the usual way, under a magnifying glass or a dissecting microscope, by enumerating the number of rows of anterior-posterior teeth extending transversely across the jaw from left to right. All rows of teeth were counted, including those at the extreme ends of the series with only one or two teeth in a row. Tooth-row counts were recorded separately for the upper and lower jaws.

Standard statistical methods were used in comparing the frequencies of median dorsal thorns and tooth-row counts by area, fish size and sex and in determining the $95 \%$ and $99 \%$ confidence intervals. For comparison of tooth-row counts of upper and lower jaws, frequencies were constructed of the differences in counts (upper-lower) for the thorny skates from the various areas and the two-tailed paired-sample t-test was applied as in Zar (1974). Only skates with total lengths of $25 \mathrm{~cm}$ and greater were used in the analysis of tooth-row counts.

\section{Results}

\section{Median dorsal thorns}

The means of the frequencies of median dorsal thorns in thorny skates from Iceland and various parts of the Northwest Atlantic extending from Davis Strait southward to Georges Bank were compared by sex, different 5-7 year periods, and $20 \mathrm{~cm}$ length groups. From the lack of statistically significant differences in 
TABLE 1. Sample information by area relevant to numbers of median dorsal thorns in thorny skates mainly from the Northwest Atlantic, 1949-72 (Fig. 3).

\begin{tabular}{|c|c|c|c|c|c|}
\hline \multirow[b]{2}{*}{ Area } & \multirow{2}{*}{$\begin{array}{l}\text { Years of } \\
\text { sampling }\end{array}$} & \multirow{2}{*}{$\begin{array}{c}\text { Length } \\
\text { range } \\
(\mathrm{cm})\end{array}$} & \multirow{2}{*}{$\begin{array}{l}\text { No. of } \\
\text { skates }\end{array}$} & \multicolumn{2}{|c|}{ No. of thorns } \\
\hline & & & & Mean & Range \\
\hline N Iceland & $1961-65$ & $20-59$ & 43 & 14.58 & $13-18$ \\
\hline Div. $1 \mathrm{ABCD}$ & $1961-65$ & $35-64$ & 28 & 15.34 & $13-18$ \\
\hline Div. $O A B^{a}$ & $1955-60$ & $11-59$ & 72 & 16.47 & $13-20$ \\
\hline Div. $2 \mathrm{H}$ & $1955-60$ & $10-55$ & 49 & 15.53 & $13-20$ \\
\hline Div. 2Jn & $1949-72$ & $10-74$ & 241 & 14.82 & $12-18$ \\
\hline Div. $2 J s+3 K$ & $1949-72$ & $10-79$ & 231 & 14.21 & $11-18$ \\
\hline Div. 3L & $1949-70$ & $10-94$ & 545 & 13.99 & $11-18$ \\
\hline Div. $3 M$ & $1949-65$ & $30-64$ & 18 & 14.44 & $13-17$ \\
\hline Div. $3 N$ & $1949-72$ & $15-99$ & 340 & 13.68 & $11-19$ \\
\hline Div. 30 & $1949-71$ & $25-104$ & 201 & 13.94 & $11-18$ \\
\hline Div. 3Ps & $1949-70$ & $15-99$ & 186 & 14.12 & $12-17$ \\
\hline Div. 4RS & $1949-72$ & $15-74$ & 369 & 13.24 & $11-16$ \\
\hline Div. 4V & $1949-70$ & $25-84$ & 54 & 13.15 & $11-16$ \\
\hline Div. $4 W X$ & $1955-70$ & $20-99$ & 27 & 13.33 & $12-16$ \\
\hline Div. $5 \mathrm{Ze}$ & $1949-70$ & $15-69$ & 66 & 13.32 & $11-16$ \\
\hline
\end{tabular}

a Includes specimens from Ungava Bay.

these comparisons, it was concluded that within-area differences due to sex, period of sampling and size of skates, if any, were negligible relative to the large differences among areas. Therefore, all data for each area were combined for the ensuing analysis (Table 1). Although a few small skates $(10-24 \mathrm{~cm})$ were examined from the various areas, most of the skates were large and were maturing or mature.

The results from the counts of median dorsal thorns (Fig. 3) showed a definite cline of decreasing means from Baffin Island (Div. OAB) and Ungava Bay (combined because data were similar) southward along the coasts of Labrador and eastern Newfoundland to the northern Grand Bank (Div. 3L), with the differences between the most northern and the more southern means of the series being increasingly significant from north to south. The means increased from southeastern Grand Bank (Div. $3 \mathrm{~N}$ ) westward to St. Pierre Bank (Div. 3Ps), but only the extreme values were significantly different. The lowest numbers of median dorsal thorns were found in thorny skates from the Gulf of St. Lawrence (Div. 4RS), Scotian Shelf (Div. $4 \mathrm{VWX}$ ) and Georges Bank (Div. 5Ze). Except for the small sample from Div. $4 \mathrm{WX}$ and the very slight overlap of the $95 \%$ confidence intervals of the Div. $3 \mathrm{~N}$ and $5 \mathrm{Ze}$ samples, the mean counts for skates from Subareas 4 and 5 were significantly lower than those from all other areas. In the northern region, the means declined significantly from the Baffin Island area (Div. $O A B$ and Ungava Bay) eastward to West Greenland (Div. $1 A B C D$ ) and thence to northern Iceland.

\section{Tooth-row counts}

The mean numbers of tooth-rows in the upper and lower jaws of thorny skates for each area and sex were initially compared by skate size groups $(10$ or $20 \mathrm{~cm}$ as

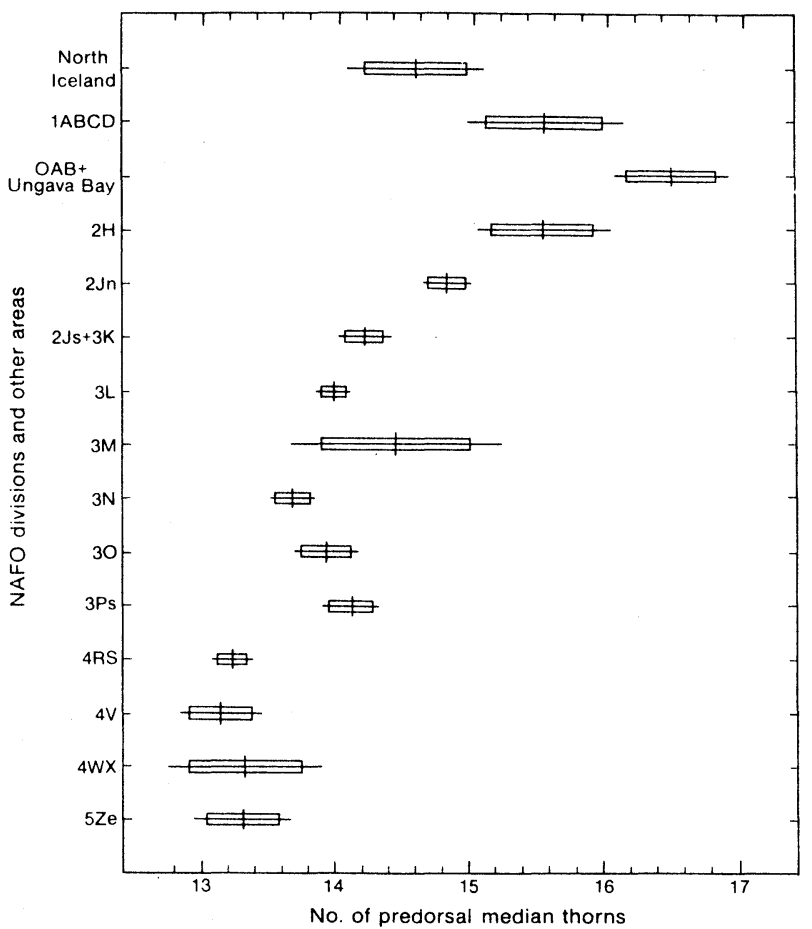

Fig. 3. Mean (median vertical line), $95 \%$ (horizontal bar) and $99 \%$ (median horizontal line) confidence limits for the numbers of median dorsal thorns of thorny skates from northern Iceland and various areas of the Northwest Atlantic.

appropriate) and by different yearly periods. The lack of significant differences between means for the 1949-54 and subsequent 5-7 year periods enabled combination of the data for the entire 1949-72 period for other comparisons. Occasionally, the mean counts for the smallest skates $(10-24 \mathrm{~cm})$ were significantly lower than those for size-groups of larger fish and they were omitted for the ensuing analyses.

In 28 pairs of comparisons of mean tooth-row for the same areas and the same or approximately the same length intervals, with 20 or more fish of each sex in each, the means were slightly greater for males than for females in 23 pairs, but none of the differences were significant. However, there was often a tendency, especially in females, for the mean tooth-row counts in fish from the same area to increase slightly with increasing fish size, but the differences between means were less than 1 or 2 tooth-rows and were not significant. For fish larger than $24 \mathrm{~cm}$, after adjustments to equalize the frequencies for males and females from each area to the lower frequency total in each case and summing over areas, mean tooth-row counts for both upper and lower jaws were slightly but not significantly higher in males than in females (Table 2).

Variations in the tooth-row counts of the upper and lower jaws were analyzed by examining the frequencies of the differences in skates from various 
TABLE 2. Summary of tooth-row counts for upper and lower jaws of thorny skates after adjustments to facilitate combination of data for all areas of the Northwest Atlantic. (The number of specimens is 852 for each sex for the statistical tests.)

\begin{tabular}{|c|c|c|c|c|c|c|}
\hline \multirow[b]{2}{*}{ Jaw } & \multirow[b]{2}{*}{ Sex } & \multirow{2}{*}{$\begin{array}{l}\text { Length } \\
\text { range } \\
(\mathrm{cm})\end{array}$} & \multicolumn{4}{|c|}{ Tooth-row number } \\
\hline & & & Range & Mean & $\mathrm{SE}$ & $t^{a}$ \\
\hline \multirow[t]{2}{*}{ Upper } & $M$ & $25-109$ & $27-48$ & 37.25 & 0.11 & $1.8 \varepsilon$ \\
\hline & $F$ & $25-94$ & $28-49$ & 36.95 & 0.11 & \\
\hline \multirow[t]{2}{*}{ Lower } & M & $25-109$ & $26-48$ & 37.41 & 0.11 & 1.5 \\
\hline & $\mathrm{F}$ & $25-94$ & $28-49$ & 37.16 & 0.11 & \\
\hline
\end{tabular}

${ }^{a}$ For $P<0.05, t>1.96$.

regions after combining samples from adjacent areas which exhibited similar patterns (Table 3 ). The results of the paired-sample t-tests were essentially the same for males and females with respect to significance or non-significance of the differences by region. The analysis, for sexes combined, showed the upper jaw counts to be significantly higher than the lower jaw counts in skates from the most southerly region and the two northern regions, particularly so in the small sample from Iceland where the difference was about two tooth-rows. In the remaining three regions from southern Labrador southward to the Grand Bank and westward to the Scotian Shelf and Gulf of St. Lawrence, the lower jaw counts were, on the average, higher than those of the upper jaw, the differences being highly significant for the southern divisions of Subarea 3 and the northern divisions of Subarea 4 . Consequently, although the data for males and females were combined, the upper and lower jaw counts were kept separate for the area comparisons (Table 4, Fig. 4).

The results from the tooth-row counts showed a cline of increasing means with differences of increasing significance from Baffin Island (Div. OAB) and Ungava Bay southward to Div. $4 W X$ and $5 Z$ Ze (Fig. 4). Thorny skates from Ungava Bay may have the lowest tooth-row counts in the western North Atlantic and those from Baffin Island the next lowest, but the samples were small and the differences between means for both upper and lower jaws were not significant. Nevertheless, the means for Ungava Bay were significantly lower than those for West Greenland (Div. 1ABCD) and Iceland and also those for all southern areas. Toothrow counts in skates from West Greenland were similar to those for the Labrador and northeastern Newfoundland areas (Div. $2 \mathrm{H}$ to $3 \mathrm{~K}$ ) but significantly lower than

TABLE 3. Frequencies of differences in tooth-row counts of upper and lower jaws of thorny skates by sex and sexes combined from various regions of the North Atlantic, 1949-72.

\begin{tabular}{|c|c|c|c|c|c|c|c|c|c|c|c|c|c|c|c|c|c|c|c|c|}
\hline \multirow[b]{2}{*}{ Region } & \multirow{2}{*}{$\begin{array}{c}\text { Length } \\
\text { range } \\
(\mathrm{cm}) \\
\end{array}$} & \multicolumn{15}{|c|}{ Frequencies of differences in jaw counts (upper $>$ lower) } & \multirow{2}{*}{$\begin{array}{c}\text { Number } \\
\text { of } \\
\text { fish }\end{array}$} & \multirow{2}{*}{$\begin{array}{c}\text { Mean } \\
\text { deviation }\end{array}$} & \multirow{2}{*}{$\begin{array}{c}\text { Standard } \\
\text { error }\end{array}$} & \multirow[b]{2}{*}{$t^{a}$} \\
\hline & & -7 & $-6-5$ & $5-4$ & -3 & -2 & -1 & 0 & 1 & 2 & 3 & 4 & 5 & 6 & 71 & & & & & \\
\hline \multicolumn{21}{|c|}{ Male } \\
\hline $\begin{array}{l}N \text { Iceland } \\
\text { Div. } 1 A B C D+O A B+\end{array}$ & $25-29$ & - & - & -- & - & - & 2 & 1 & 5 & 8 & 3 & 2 & $2-$ & - & - & & 23 & 2.000 & 0.333 & $6.01^{* *}$ \\
\hline Ungava Bay $+2 \mathrm{HJn}$ & $25-74$ & - & - & 2 & 10 & 22 & 29 & 36 & 26 & 23 & 17 & 5 & $4-$ & - & $1-$ & & 176 & 0.307 & 0.156 & $1.97^{\star}$ \\
\hline Div. $2 \mathrm{Js}+3 \mathrm{~K}$ & $25-79$ & - & - & -1 & 12 & 7 & 37 & 31 & 19 & 15 & 6 & 1 & $1-$ & - - & - & & 130 & -0.115 & 0.147 & 0.78 \\
\hline Div. 3LMNOPs & $25-106$ & - & 2 & 622 & 38 & 70 & 87 & 94 & 83 & 47 & 30 & 8 & $7-$ & - & - & & 494 & -0.277 & 0.093 & $2.98^{\star *}$ \\
\hline Div. 4RSTV & $25-84$ & 1 & - & 414 & 19 & 33 & 44 & 32 & 23 & 19 & 5 & $1-$ & -- & -- & - & & 195 & -0.872 & 0.139 & $6.27^{\star *}$ \\
\hline Div. $4 W X+5 Z e$ & $25-99$ & - & - & 11 & 1 & 2 & 6 & 11 & 6 & 11 & 2 & - & 3 & - & - & & 44 & 0.614 & 0.317 & 1.94 \\
\hline Total all areas & $25-106$ & 1 & 212 & 240 & 801 & 1342 & 2052 & 2051 & 16212 & 23 & 631 & 171 & $17-$ & - & $1-$ & - & 1,062 & -0.184 & 0.063 & $2.92^{\star \star}$ \\
\hline \multicolumn{21}{|c|}{ Female } \\
\hline $\begin{array}{l}N \text { Iceland } \\
\text { Div. } 1 A B C D+O A B+\end{array}$ & $25-56$ & - & - & -- & - & - & - & 4 & - & 5 & 4 & 2 & $1-$ & - & - & & 16 & 2.188 & 0.390 & $5.61^{\star \star}$ \\
\hline Ungava Bay $+2 \mathrm{HJn}$ & $25-64$ & - & -1 & 1 & 3 & 9 & 30 & 25 & 17 & 15 & 8 & 4 & - & $1-$ & -1 & - & 114 & 0.237 & 0.171 & 1.39 \\
\hline Div. 2Js + 3K & $25-69$ & - & - & -3 & 2 & 7 & 8 & 24 & 12 & 9 & 4 & - & -1 & - & - & - & 69 & 0.029 & 0.199 & 0.15 \\
\hline Div. 3LMNOPS & $25-94$ & - & -13 & 1333 & 571 & 1341 & 1381 & 1741 & 130 & 92 & 511 & 13 & 5 & $1-$ & - & 1 & 842 & -0.253 & 0.070 & $3.61^{\star *}$ \\
\hline Div. 4RSTV & $30-74$ & - & 11 & 113 & 20 & 29 & 50 & 39 & 27 & 10 & 5 & - & - - & - & - & - & 195 & -0.867 & 0.124 & $6.99^{\star *}$ \\
\hline Div. $4 W X+5 Z e$ & $25-89$ & - & 11 & 11 & 2 & 1 & - & 11 & 9 & 7 & 1 & 1 & 1 & - & - & - & 36 & 0.333 & 0.380 & 0.88 \\
\hline Total all areas & $25-94$ & - & 216 & 1651 & 841 & 1802 & 2262 & 2771 & 19513 & 138 & 732 & 20 & 7 & $2-$ & - & 1 & 1,272 & -0.241 & 0.056 & $4.30^{* *}$ \\
\hline \multicolumn{21}{|c|}{ Sexes Combined } \\
\hline $\begin{array}{l}N \text { Iceland } \\
\text { Div. } 1 A B C D+O A B+\end{array}$ & $25-29$ & - & - & -- & - & - & 2 & 5 & 5 & 13 & 7 & 4 & 3 & - & -- & - & 39 & 2.077 & 0.250 & $8.31^{\star *}$ \\
\hline Ungava Bay $+2 \mathrm{HJn}$ & $25-74$ & - & -2 & 23 & 13 & 31 & 59 & 61 & 43 & 38 & 25 & 9 & 4 & 1 & $1-$ & - & 290 & 0.279 & 0.116 & $2.41^{*}$ \\
\hline Div. 2Js + 3K & $25-79$ & - & - & -4 & 14 & 14 & 45 & 55 & 312 & 24 & 10 & 1 & 1 & -- & -- & - & 199 & -0.065 & 0.118 & 0.55 \\
\hline Div. 3LMNOPs & $25-106$ & - & 210 & 1955 & 952 & 2042 & 2252 & 2682 & 21313 & 139 & 812 & 211 & 12 & 1 & - & 1 & 1,336 & -0.262 & 0.056 & $4.68^{\star *}$ \\
\hline Div. 4RSTV & $25-84$ & 1 & 15 & 527 & 39 & 62 & 94 & 71 & 50 & 29 & 10 & 1 & - & - & - & - & 390 & -0.869 & 0.093 & $9.34 * *$ \\
\hline Div. $4 W X+5 Z e$ & $25-99$ & - & 12 & 22 & 3 & 3 & 6 & 22 & 15 & 18 & 3 & 1 & $4-$ & - & -- & - & 80 & 0.488 & 0.243 & $2.01^{\star}$ \\
\hline Total all areas & $25-106$ & 1 & 428 & 2891 & 1643 & 3144 & 4314 & 4823 & 3572 & 2611 & 1363 & 372 & 24 & 2 & 1 & 1 & 2,334 & -0.215 & 0.042 & $5.12^{\star *}$ \\
\hline
\end{tabular}

\footnotetext{
a Significant levels: * implies $\mathrm{P}<0.05$ and ** implies $\mathrm{P}<0.01$.
} 
TABLE 4. Sample information by area relevant to number of rows of teeth in upper and lower jaws of thorny skates mainly from the Northwest Atlantic, 1949-72 (Fig. 4).

\begin{tabular}{|c|c|c|c|c|c|c|c|}
\hline \multirow[b]{3}{*}{ Area } & \multirow{3}{*}{$\begin{array}{c}\text { Years of } \\
\text { sampling }\end{array}$} & \multirow{3}{*}{$\begin{array}{l}\text { Length } \\
\text { range } \\
(\mathrm{cm})\end{array}$} & \multirow{3}{*}{$\begin{array}{l}\text { No. of } \\
\text { skates }\end{array}$} & \multicolumn{4}{|c|}{ No. of rows of teeth } \\
\hline & & & & \multicolumn{2}{|c|}{ Upper jaw } & \multicolumn{2}{|c|}{ Lower jaw } \\
\hline & & & & Mean & Range & Mean & Range \\
\hline N Iceland & 1961-65 & $25-29$ & 39 & 39.36 & $35-46$ & 37.28 & $33-43$ \\
\hline Div. $1 A B C D$ & $1961-65$ & $35-64$ & 25 & 35.36 & $31-40$ & 35.04 & $32-39$ \\
\hline Div. OAB & $1955-60$ & $25-49$ & 19 & 33.90 & $30-40$ & 33.63 & $29-39$ \\
\hline Ungava Bay & $1955-60$ & $25-59$ & 18 & 31.50 & $27-36$ & 31.61 & $26-36$ \\
\hline Div. $2 \mathrm{H}$ & $1955-60$ & $25-54$ & 45 & 34.58 & $31-40$ & 34.13 & $29-39$ \\
\hline Div. 2Jn & $1949-72$ & $25-74$ & 177 & 34.49 & $28-40$ & 34.22 & $28-42$ \\
\hline Div. $2 J s+3 K$ & $1949-72$ & $25-79$ & 198 & 35.50 & $29-44$ & 35.50 & $29-42$ \\
\hline Div. 3L & $1949-72$ & $25-94$ & 485 & 36.99 & $28-45$ & 37.08 & $29-47$ \\
\hline Div. 3M & $1949-65$ & $30-64$ & 23 & 36.83 & $31-42$ & 37.65 & $32-44$ \\
\hline Div. 3N & $1949-71$ & $25-99$ & 342 & 37.40 & $30-46$ & 37.75 & $30-47$ \\
\hline Div. 30 & $1949-72$ & $25-104$ & 324 & 38.68 & $31-47$ & 39.00 & $32-48$ \\
\hline Div. 3Ps & $1949-72$ & $25-99$ & 160 & 38.55 & $30-49$ & 38.84 & $32-47$ \\
\hline Div. 4RS & $1949-72$ & $25-74$ & 335 & 36.44 & $30-44$ & 37.32 & $31-47$ \\
\hline Div. 4V & $1949-70$ & $25-84$ & 54 & 37.28 & $28-45$ & 37.98 & $30-44$ \\
\hline Div. $4 W X$ & $1955-70$ & 25-99 & 27 & 42.15 & $37-47$ & 41.89 & $36-49$ \\
\hline Div. $5 Z$ e & $1949-70$ & $25-69$ & 53 & 42.53 & $36-48$ & 41.43 & $36-48$ \\
\hline
\end{tabular}

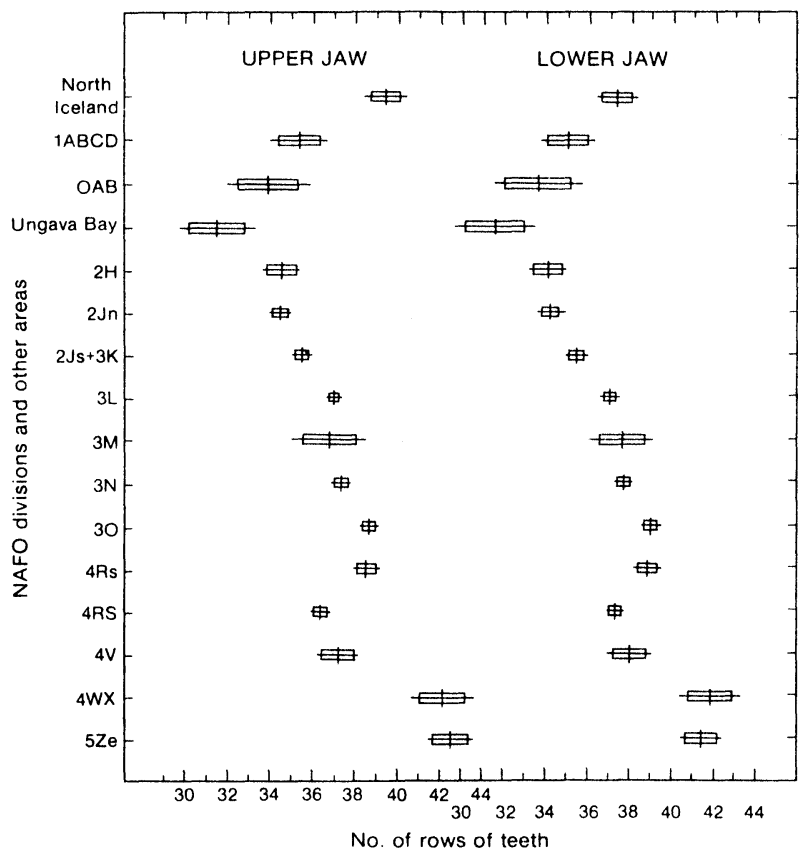

Fig. 4. Mean (median vertical line), 95\% (horizontal bar) and $99 \%$ (median horizontal line) confidence limits for the numbers of tooth-rows in the upper and lower jaws of thorny skates from northern Iceland and various areas of the Northwest Atlantic.

most of the mean counts for areas from Div. 3L southward. There are two relatively separate series of toothrow counts in Fig. 4, the eastern one extending southward from Baffin Island (Div. OAB) to the southwestern Grand Bank and St. Pierre Bank (Div. 30 and 3Ps), and the western series extending from the northern Gulf of St. Lawrence (Div. 4RS) southward to Georges Bank (Div. 5Ze). Div. 4RS corresponds in latitude with the southern part of Div. $3 \mathrm{~K}$ and the northern part of Div. 3L, and the mean tooth-row counts for skates in Div. 4RS were generally similar to those for
Div. 3L and lower than those for Div. 30 and 3Ps. The means for the northern part of the Scotian Shelf (Div. $4 \mathrm{~V}$ ) were slightly but not significantly higher than those for Div. 4RS, but they were significantly lower than those for the warmer southern part of the Scotian Shelf (Div. 4WX) and for Georges Bank (Div. 5Ze).

\section{Discussion}

\section{Median dorsal thorns}

In this paper, thorny skates of the Northwest Atlantic are shown to have higher numbers of median dorsal thorns in the northern (colder) than in southern (warmer) regions, the means varying from 16.47 (range 13-20) in the Baffin Island-Ungava Bay region to 13.22 (range 11-16) on the Scotian Shelf. Vladykov (1933) reported a thorny skate from Hudson Bay with 19 median thorns, and he (1934) called attention to Clark's (1926) low counts of median thorns in skates from the North Sea and Iceland in contrast to Jensen's (1914) higher counts in fish from West Greenland. Bigelow and Schroeder (1953) reported a range of 12-14 median dorsal thorns in small specimens and 11-16 in larger specimens of thorny skate from the Gulf of Maine.

The lack of knowledge about the location and development of egg capsules of thorny skates in the various parts of the Northwest Atlantic by season, developmental period, depth and temperature makes it impossible to deal in detail with the reasons for the spatial differences in the numbers of median dorsal thorns. The egg capsules are laid on the bottom, and, from information on developmental periods for other skates (Clark, 1922; Richards et al., 1963; Perkins, 1965), development to hatching in thorny skates may 
vary from about 6 months at favorably high temperatures to possibly years in areas where temperatures remain persistently low throughout the year. Egg capsules were found in mature females during all seasons of the year in most of the study areas (Templeman, 1982) except in the northern part of the region which was not studied in late autumn and winter months.

Thorny skates commonly occur on the bank and coastal shelf areas, where, during most of the year in the northern (Baffin Island and Labrador) and during winter-spring in the southern (Grand Bank and Gulf of St. Lawrence to Georges Bank) parts of the region, egg capsules laid at moderate depths would be subject to low temperatures, these in the north being several degrees lower than those in the south. In general, also, bottom temperatures off Baffin Island are lower than those on the banks off West Greenland. It is probable, therefore, that different temperatures during development of skates within the egg capsules laid in different areas account for the variation in mean number of median dorsal thorns, with slower development and consequent higher numbers of thorns occurring at lower temperatures. This phenomenon is typical of the Atlantic cod (Gadus morhua) populations of the region, with an inverse relationship between vertebral numbers and temperature (Templeman, 1981). Because thorny skate do not undergo extensive migrations (Templeman, 1984), genetic factors may also influence the numbers of median dorsal thorns.

The numbers of precaudal vertebrae in a small number of $R$. ocellata from the Gulf of St. Lawrence were signficantly higher than in those from Georges Bank to Mid-Atlantic Bight (McEachran and Martin, 1977). This is the same direction as the decline in numbers of median dorsal thorns in thorny skates from Baffin Island and Ungava Bay southward, but the numbers of thorns in thorny skates from the northern Gulf of St. Lawrence (Div. 4RS) and Georges Bank (Div. 5Ze), in this paper, were not significantly different.

\section{Tooth-row counts}

In this paper, the tooth-row counts of thorny skates increased from low ranges of 27-36 and 26-36 (upper and lower jaws respectively) in Ungava Bay to high ranges of 36-48 and 36-49 in the southern Scotian Shelf-Georges Bank region. The scanty data in the literature on tooth-row counts of thorny skates from different parts of the Northwest Atlantic were in general agreement with the data in this paper: Massachusetts Bay to Sable Island on the Scotian Shelf (Bigelow and Schroeder, 1934), West Greenland (Jensen, 1948), and Hudson Bay (Vladykov, 1933). Also, the tooth-row data reported by Bigelow and Schroeder (1953) for the Northwest Atlantic and Norwegian waters were similar in range to Georges Bank (Div. 5Ze) data in this paper.
There are also tooth-row data from the southern hemisphere for $R$. radiata and its close relative Raja doellojuradoi, which is so similar to $R$. radiata that probably only distance and custom deep it from being called R. radiata (Bigelow and Schroeder, 1953; Hulley, 1970). In 10 specimens of $R$. doellojuradoi from the Patagonian region of Argentina and the Falkland Islands $\left(44^{\circ} 25^{\prime} \mathrm{S}\right.$ to $\left.52^{\circ} 54^{\prime} \mathrm{S}\right)$, there were $28-34$ rows of teeth in the upper jaw (Norman, 1937). Each of two specimens from the same region had 31 and 32 rows of teeth in the upper and lower jaws respectively (Pozzi, 1936). These skates were from the southernmost (coolest) part of the range of the species in the southern hemisphere, and the tooth-row counts are comparable to those in the upper and lower jaws of $R$. radiata from Ungava Bay. Maximum sizes and presumably sizes at sexual maturity of $R$. doellojuradoi are also comparable to those of $R$. radiata from the northern part of the Northwest Atlantic, the largest $R$. doellojuradoi being reported as $53 \mathrm{~cm}$ total length (Hulley, 1970). In contrast, two specimens of $R$. radiata ( 57 and $62 \mathrm{~cm}$ total length), trawled west of Cape Town $\left(34^{\circ} \mathrm{S}\right)$ in the warmer South African waters, had 37-39 rows of teeth in the upper jaw (Hulley, 1970), comparable to the counts in thorny skates from the Grand Bank. Thus, the trends in numbers of tooth-rows were similar in direction for the thorny skates from the northern and southern hemispheres in relation to latitude and temperature.

The pattern of increasing tooth-row counts with decreasing latitude (and increasing temperature) is evident in other skates of the Northwest Atlantic. In 13 Raja erinacea from the Scotian Shelf, Templeman (1965) reported the ranges of tooth-row counts of the upper and lower jaws as being 44-55 and 47-54 respectively, the mean being 50 in each case. Farther south off the United States (Block Island Sound), 41 R. erinacea had upper jaw tooth-row counts of 47-64, the mean being 54 (Richards et al., 1963). McEachran and Martin (1977) found a highly significant difference between tooth-row counts in the upper jaw of $R$. ocellata from the Gulf of St. Lawrence and those from Georges Bank and Mid-Atlantic Bight, the mean counts being 74.0 and 87.7 respectively. They attributed the difference to character displacement of $R$. ocellata in the Gulf of St. Lawrence toward the smaller tooth-row numbers of $R$. erinacea. The Gulf of St. Lawrence $R$. ocellata, like the $R$. radiata from northern waters, matured at smaller sizes and grew to smaller maximal sizes in colder water than those from more southerly areas off the United States coast. Thus, from a biological and ecological viewpoint, the difference in mean tooth-row counts of $R$. ocellata from the Gulf of St. Lawrence and northeastern United States were similar in direction and, allowing for the greater number of tooth-rows in $R$. ocellata, were about the same magnitude as the differences in mean number of tooth-rows of the upper jaw 
of thorny skates from the northern Gulf of St. Lawrence (36.44) and Georges Bank (42.53), in this paper.

The number of tooth-rows in both $R$. erinacea and R. ocellata from Mid-Atlantic Bight, Georges Bank and Gulf of Maine increased until the fish obtained about half the mean size at sexual maturity, and neither species was sexually dimorphic with respect to the number of tooth-rows in the upper jaw (McEachran and Musick, 1973). In R. radiata of this paper, there was a tendency, especially in females, toward some increase in mean tooth-row count with increase in fish length, but increases were not significant except when 10-24 cm skates were compared with size-groups of larger fish.

The pattern of increasing tooth-row counts by about 10 rows for both upper and lower jaws with decreasing latitude (and increasing temperature) from southern Baffin Island (Div. OAB) and Ungava Bay to the southern part of the Scotian Shelf and Georges Bank (Div. 4WX and 5Ze) was in the opposite direction to that for median dorsal thorns. Although this increase in tooth-row counts corresponded with increasing maximum sizes of the thorny skates in the region from Baffin Island-Ungava Bay to Grand Bank and St. Pierre Bank (Div. 3LNOPs) (Table 4) due to increasing sizes at sexual maturity (Templeman, 1982), there was no similar increase in maximum size of skates to account for the large increase in tooth-row counts between the Grand Bank-St. Pierre Bank region (Div. 3LNOPs) and the most southerly areas (Div. 4WX and 5ZE). The trend in tooth-row counts was unlikely to have been due to variation in the size of skates. For $25 \mathrm{~cm}$ and larger skates, there was some indication, more so for females than for males, of an increase in tooth-row number with length, but the small increases related to length within an area were not significant. Similarly, opposite trends in the two meristic characters were evident in the northern areas, with increasing toothrow numbers and decreasing median dorsal thorns from the Baffin Island and Ungava Bay areas eastward to West Greenland and thence to northern Iceland, in association with increasing temperatures.

Although the trends in numbers of tooth-rows and median thorns were generally in opposite directions, some irregularities were evident. The mean number of median dorsal thorns in the Gulf of St. Lawrence (Div. 4RS) was significantly lower than those for all northern areas (Subareas $0-3$ ) and similar to those for the Scotian Shelf (Div. 4VWX) and Georges Bank (Div. 5Ze), whereas the tooth-row counts for Div. 4RS were intermediate between those of Labrador-Northeast Newfoundland (Div. $2 \mathrm{H}-3 \mathrm{~K}$ ) and the southern Grand Bank and St. Pierre Bank areas (Div. 3NOPs) and significantly lower than those for Div. $4 \mathrm{WX}$ and $5 \mathrm{Ze}$ (Fig. 3 and 4). Also, the trends in the two meristic characters for Div. $3 \mathrm{~N}, 3 \mathrm{O}$ and $3 \mathrm{Ps}$ tended to be in the same direction rather than in opposite directions.

Thorny skates typically do not engage in long migrations (Templeman, 1984), and the meristic differences in this paper provide evidence for the separation of the populations or stocks of the Northwest Atlantic. Especially where high or low numbers of median dorsal thorns or tooth-rows were present in skates from one area and lacking in another (Tables 1 and 4), little or no intermixing occurs. Additional evidence is available from the sizes of egg capsules of this species (Templeman, 1982).

\section{Acknowlegdements}

I am especially grateful to E. M. LeGrow and H. R. Mullett who assisted greatly in gathering the data, to $S$. H. Lee, J. V. Arklie, J. R. Burt, and C. H. Riche for assistance in assembling the data, and to E. L. Rowe for the skate photographs.

\section{References}

ANDRIYASHEV, A. P. 1954. Fishes of the northern seas of the USSR. Dokl. Akad. Nauk SSSR, 53, 566 p. (Transl. from Russian by Israel Prog. for Sci. Transl., 1964.)

BIGELOW, H. B., and W. C. SCHROEDER. 1934. Marsipobranchii (lampreys), Elasmobranchii (sharks and rays), Holocephali (chimaeroids). Canad. Atlant. Fauna, No. 12, 38 p.

1953. Fishes of the western North Atlantic: Sawfishes guitarfishes, skates and rays. Mem. Sears Fdn. Mar. Res., 1(2), 514 p.

CLARK, J. R., and V. D. VLADYKOV. 1960. Definition of haddock stocks of the northwestern Atlantic. Fish. Bull. U.S., 60: 284-296.

CLARK, R. S. 1922. Rays and skates (Raiae): egg capsules and young. J. Mar. Biol. Assoc. U.K., 12(N.S.): 577-643.

1926. Rays and skates: a revision of the European species. Fish. Bd. Scot. Sci. Invest., 1926 (1), 66 p.

1929. Raia radiata. ICES Faune Ichthyol. AtI. N., No. 44.

HULLEY, P. A. 1970. An investigation of the Rajidae of the west and south coasts of southern Africa. Ann. S. Afr. Mus., 55: 151-220.

JENSEN, A. S. 1914. The selachians of Greenland. Mindeskr. for J. Steenstrup, København, 2(30), 40 p.

1948. Contributions to the ichthyofauna of Greenland 8-24 Spolia Zool. Mus. Hauniensis, 9, 182 p.

McEACHRAN, J. D., and C. O. MARTIN. 1977. Possible occurrence of character displacement in the sympatric skates Raja erinacea and R. ocellata (Pisces: Rajidae). Environ. Biol. Fish., 2: 121-130.

MCEACHRAN, J. D., and J. A. MUSICK. 1973. Characters for distinguishing between immature specimens of the sibling species, Raja erinacea and Raja ocellata (Pisces: Rajidae). Copeia, 1973: 238-250.

1975. Distribution and relative abundance of seven species of skates (Pisces: Rajidae) which occur between Nova Scotia and Cape Hatteras. Fish. Bull. U.S., 73: 110-136.

NAFO. 1983. Fishery statistics for 1981. NAFO Stat. Bull., 31 (Table 3): 53-55.

NORMAN, J. R. 1937. Coast fishes. Part 2. The Patagonian region. Discovery Rep., 16, $150 \mathrm{p}$.

PERKINS, E. 1965. Incubation of fall-spawned eggs of the little skate, Raja erinacea Mitchill. Copeia, 1965: 114-115.

POZZI, A. J. 1936. Descripción de la nueva especie de raya, Raja 
doellojuradoi Pozzi. An. Mus. Argent. Cienc. Nat., 38: 418-422. RICHARDS, S. H., D. MERRIMAN, and L. H. CALHOUN. 1963. Studies on the marine resources of southern New England. IX. The biology of the little skate Raja erinacea Mitchill. Bull. Bingham Oceanog. Coll., 18(3): 4-67.

SCHMIDT, J. 1930. The Atlantic cod (Gadus callarias L.) and local races of the same. In: Racial Investigations X, C. R. Lab. Carlsberg, 18(6), $71 \mathrm{p}$

SCOTT, J. S. 1982. Depth, temperature and salinity preferences of common fishes of the Scotian Shelf. J. Northw. Atl. Fish. Sci., 3 : 29-39.

TEMPLEMAN, W. 1965. Some resemblances and differences between Raja erinacea and Raja ocellata, including a method of separating mature and large immature individuals of these two species. $J$. Fish. Res. Board Can., 22: 899-912.

1981. Vertebral numbers in Atlantic cod, Gadus morhua, of the
Newfoundland and adjacent areas, 1947-71, and their use for delineating cod stocks. J. Northw. Atl. Fish. Sci., 2: 21-45.

1982. Development, occurrence and characteristics of the egg capsules of the thorny skate, Raja radiata, in the Northwest Atlantic. J. Northw. Atl. Fish. Sci., 3: 47-56.

1984. Migrations of thorny skate, Raja radiata, tagged in the Newfoundland area. J. Northw. Atl. Fish. Sci., 5: 55-63.

VLADYKOV, V. D. 1933. Biological and oceanographic conditions in Hudson Bay. 9. Fishes from the Hudson Bay region (except the Coregonidae). Contrib. Can. Biol. Fish., N.S., 8: 13-49.

1934. Environmental and taxonomic characters of fishes. Trans. Roy. Can. Inst., 20(1): 99-140.

1935. Haddock races along the North American coast. Biol. Board Can. Atlant. Prog. Rep., 14: 3-7.

ZAR, J. H. 1974. Biostatistical analysis. Prentice-Hall Inc., Englewood Cliffs, N. J., 620 p. 
